\title{
Effect of inhibition of prostaglandin synthesis on induced bronchial hyperresponsiveness
}

\author{
EH WALTERS
}

From the Asthma Research Unit, Sully Hospital, Penarth, Cardiff

ABSTRACT Two groups of normal subjects were immunised with live attenuated influenza virus given by the intranasal route. One group was then treated with placebo capsules for 48 hours. At the end of this time an increase in sensitivity to inhaled histamine was found but with a coincident decrease in reactivity. The other group was treated with indomethacin (50 $\mathrm{mg}$ four times daily). The increase in sensitivity associated with influenza vaccination was prevented but there was a significant increase in reactivity. It is proposed that prostaglandins released as part of the inflammatory response in the airways after viral infection may be concerned in induction of the changes in response to histamine observed under these conditions.

Exacerbations of symptoms in asthmatic patients are frequently associated with acute viral infections of the respiratory tract. ${ }^{12}$ At such times the response to inhaled bronchoconstrictor agents has also been shown to be increased. ${ }^{34}$ This hyperresponsiveness of the airways develops within two to three days of the appearance of symptoms and lasts for several weeks after symptoms resolve.

Viral infections of the respiratory tract may be associated with some degree of narrowing of the small airways. ${ }^{56}$ The changes in airways responsiveness observed in these studies, however, did not correlate temporally with changes in airways calibre ${ }^{7}$ and even occurred in their absence. ${ }^{8}$

Hyperresponsiveness of the airways has been found 24 hours after subcutaneous injection of vaccine containing killed influenza virus into patients with stable asthma. ${ }^{9}$ This lasted 72 hours and occurred without a change in baseline spirometry values. Live attenuated influenza virus when given by nasal drops and aerosol also induced hyperresponsiveness in four of six normal subjects. ${ }^{10}$ This was found at 48 hours but was less by four days and gone by nine days.

Endoscopy of patients with non-pneumonitic influenza $\mathrm{A}$ infection has shown inflammation of tracheal and bronchial mucosa. ${ }^{11}$ The present study was performed to investigate whether the prostaglandins generated by such an inflammatory reaction are concerned in the development of the hyper-

Address for reprint requests: Dr EH Walters, co Asthma Research Unit, Sully Hospital, Cardiff, S Glam. Correspondence: University of California Cardiovascular Research Institute, San Francisco, USA. responsiveness induced by infection. Normal volunteers were given a vaccine of live attenuated influenza virus via the nasal route and the effects of indomethacin, a potent inhibitor of prostaglandin synthesis, on subsequent responses to inhaled histamine were observed.

\section{Methods}

Twenty normal, non-atopic, non-asthmatic volunteers took part after informed consent had been obtained. They had a mean age of 29 years (range 19-50) and were non-smokers.

The general method was similar to that used in the other study reported in this issue (pp 188-94). On the first day of study a histamine inhalation doseresponse curve was constructed. The concentrations of histamine diphosphate ranged from $0 \cdot 1 \mathrm{mg} / \mathrm{ml}$ to $50 \mathrm{mg} / \mathrm{ml}$ in nine increments and were administered via a Wright's nebuliser driven by compressed air at $20 \mathrm{lb} / \mathrm{in}^{2}(137.9 \mathrm{kPa})$. Each dose consisted of 10 tidal breaths of the appropriate concentration of solution and was standardised by a respiratory metronome set at 18 breaths/min. Doses were given at three-minute intervals.

Specific airways conductance (sGaw) was measured in a constant-volume whole-body plethysmograph, at each time point the last six of seven technically satisfactory readings being recorded. Baseline sGaw was taken as the mean of two such sets of readings, obtained five minutes apart just before the first dose of histamine and after the subject had been sitting quietly in the laboratory for 15 minutes. sGaw was measured one and a half to three minutes 
after each dose of histamine. Resistance and volume angles were measured with the aid of an electronic resolver displayed on the oscilloscope screen. The actual numerical values of the angles were thus out of sight of the operator until the end of the measuring procedure in the hope of preventing subjective bias. At the end of the first histamine challenge 10 $\mathrm{ml}$ of venous blood were taken and spun down and the serum was stored at $-20^{\circ} \mathrm{C}$. A single dose of Nasoflu RIT 4199 vaccine was then administered intranasally. This consisted of live attenuated influenza virus of the A/Alaska/77 (H3N2) strain and was provided by Smith Klein, Belgium, as an off-white pellet contained in a glass vial with a separate plastic tube containing clear colourless sterile diluent (dextrose solution). The vaccine was reconstituted with the diluent and administered as drops into both nares, the subject lying supine with the head extended. After a few seconds subjects were asked to sniff gently and then remain supine for about 10 minutes. They avoided sneezing and nose blowing for the next 30 minutes if possible.

Subjects were then immediately allocated to treatment with either indomethacin $(50 \mathrm{mg}$ four times a day orally) or identical placebo capsules. This was done in random order and double blind, 10 subjects entering each group. Treatment continued for $\mathbf{4 8}$ hours, after which a second histamine challenge was performed one and a half to two hours after the last capsule. Each subject at that time was questioned about the presence of coryzal symptoms.

Three weeks after immunisation a second blood sample was obtained and the serum stored. Serum samples from all subjects were subsequently tested for a greater than four-fold rise in the titre of haemagglutination inhibition (HI) antibody to the A/Alaska influenza strain.

The regression line of the descending part of each log-cumulative histamine dose-response curve was computed for values with a $15 \%$ or greater fall in sGaw. The dose of histamine which caused a $20 \%$ fall in sGaw $\left(D_{20}\right)$ was calculated from this and used as an index of airways sensitivity. The slope of the regression line was taken as the reactivity of the airways. Values of baseline sGaw, $\log \mathrm{D}_{20}$, and slope were compared with Student's $t$ test. Linear regression analyses were performed on control values of baseline sGaw, $\mathrm{D}_{20}$, and slope and also on changes in these indices.

\section{Results}

The results are shown in the figure and in tables $1 \stackrel{3}{\triangle}$ and 2 . Inadvertently, on entry to the study the placebo-treatment group had a higher mean baseline value of sGaw than the indomethacintreatment group: 3.6 compared with $3.1 \mathrm{~s}^{-1} \mathrm{kPa}^{-1}$ respectively $(\mathrm{p}<0.005)$. The initial mean value for the slope (reactivity) was also greater in the placebo group: -2.05 compared with $-1.62 \mathrm{~s}^{-1} \mathrm{kPa}^{-1}\left(\mathrm{p}<\frac{\mathrm{O}}{8}\right.$ $0.05)$. There was, however, no significant difference in mean value of $\log D_{20}$ for the two groups.

Forty-eight hours after immunisation the placebo treatment group showed a small and non-significant

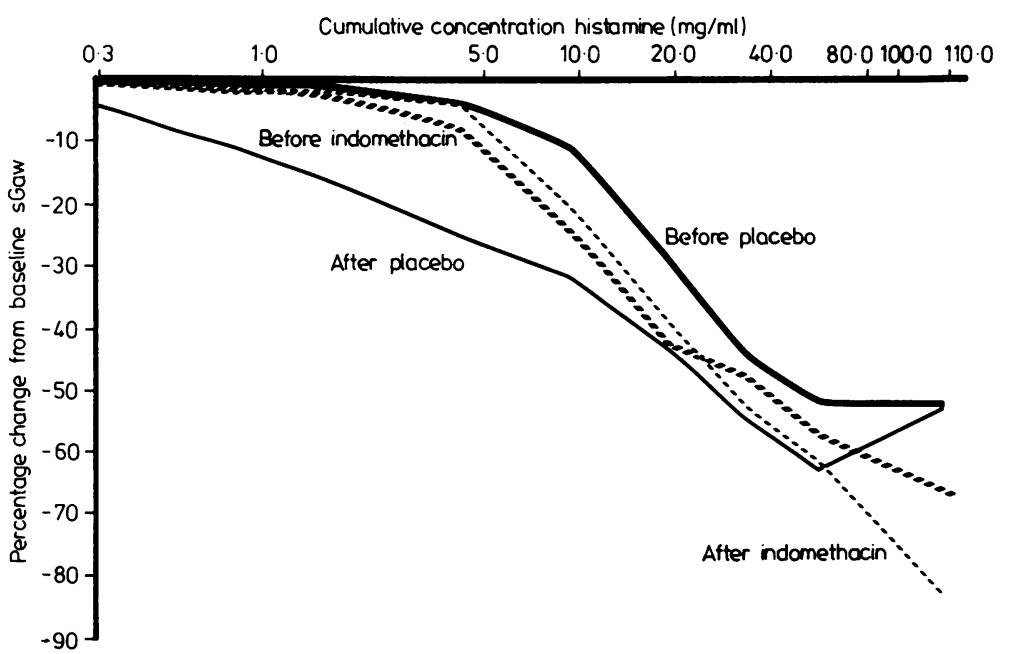

Mean inhalation cumulative dose-response curves for histamine before and 48 hours after immunisation with live attenuated infuenza virus given intranasally for two groups of 10 normal subjects, one group treated during the intervening period with indomethacin and the other with placebo. 
Table 1 Histamine challenge in placebo-treatment group, performed before and 48 hours after immunisation with live attenuated inftuenza virus (individual data derived from the regression line of the descending part of each log-cumulative dose-response curve)

\begin{tabular}{|c|c|c|c|c|c|c|c|}
\hline \multirow[t]{2}{*}{ Subject No } & \multicolumn{3}{|c|}{ Before immunisation } & \multicolumn{3}{|c|}{48 hours after immunisation and placebo capsules } & \multirow[t]{2}{*}{ Outcome } \\
\hline & $\begin{array}{l}\text { Baseline } s G a w \\
\left(s^{-1} \mathrm{KPa}^{-1}\right)\end{array}$ & $D_{20}(m g / m l)$ & $\begin{array}{l}\text { Slope } \\
\left(s^{-1} \mathrm{kPa}^{-1}\right)\end{array}$ & $\begin{array}{l}\text { Baseline sGaw } \\
\left(s^{-1} \mathrm{kPa}^{-1}\right)\end{array}$ & $D_{20}(m g / m l)$ & $\begin{array}{l}\text { Slope } \\
\left(s^{-1} \mathrm{kPa}^{-1}\right)\end{array}$ & \\
\hline $\begin{array}{r}1 \\
2 \\
3 \\
4 \\
5 \\
6 \\
7 \\
8 \\
9 \\
10\end{array}$ & $\begin{array}{l}3 \cdot 5 \\
3 \cdot 8 \\
4 \cdot 1 \\
4 \cdot 1 \\
3 \cdot 1 \\
2 \cdot 9 \\
2 \cdot 9 \\
3 \cdot 5 \\
3 \cdot 8 \\
4 \cdot 1\end{array}$ & $\begin{array}{r}7 \cdot 8 \\
6 \cdot 6 \\
10 \cdot 7 \\
12 \cdot 3 \\
8.5 \\
19 \cdot 5 \\
45 \cdot 7 \\
75.9 \\
16.6 \\
5 \cdot 1\end{array}$ & $\begin{array}{l}-2.79 \\
-2.26 \\
-2.59 \\
-2.56 \\
-2.27 \\
-1.20 \\
-1.24 \\
-1.77 \\
-1.67 \\
-2.14\end{array}$ & $\begin{array}{l}3 \cdot 6 \\
3 \cdot 3 \\
3 \cdot 9 \\
3 \cdot 9 \\
2 \cdot 7 \\
2 \cdot 9 \\
3 \cdot 2 \\
3 \cdot 6 \\
3 \cdot 4 \\
4 \cdot 1\end{array}$ & $\begin{array}{r}2 \cdot 1 \\
0 \cdot 8 \\
1 \cdot 2 \\
2 \cdot 5 \\
3 \cdot 2 \\
0 \cdot 4 \\
17 \cdot 1 \\
26 \cdot 3 \\
18 \cdot 2 \\
5 \cdot 8\end{array}$ & $\begin{array}{l}-1.60 \\
-1.10 \\
-1.29 \\
-1.64 \\
-0.90 \\
-0.55 \\
-0.69 \\
-1.57 \\
-1.24 \\
-2.39\end{array}$ & $\begin{array}{l}\text { C/A } \\
\text { A } \\
\text { C } \\
\text { A } \\
\text { C } \\
\text { C } \\
\text { A } \\
\text { ClA }\end{array}$ \\
\hline $\begin{array}{l}\text { Mean } \\
\text { SD } \\
\text { SEM }\end{array}$ & $\begin{array}{l}3 \cdot 6 \\
0.48 \\
0.15\end{array}$ & $\begin{array}{r}20.9 \\
22.65 \\
7.17\end{array}$ & $\begin{array}{r}-2.05 \\
0.56 \\
0.18\end{array}$ & $\begin{array}{l}3 \cdot 5 \\
0 \cdot 45 \\
0 \cdot 14\end{array}$ & $\begin{array}{l}7 \cdot 8 \\
9 \cdot 25 \\
2 \cdot 93\end{array}$ & $\begin{array}{r}-1.30 \\
0.54 \\
0.17\end{array}$ & \\
\hline
\end{tabular}

C-coryzal symptoms; A-greater than four-fold rise in haemagglutination-inhibition antibody.

Table 2 Histamine challenge in indomethacin-treatment group, performed before and 48 hours after immunisation with live attenuated infuenza virus (individual data derived from the regression line of the descending part of each log-cumulative dose-response curve)

\begin{tabular}{|c|c|c|c|c|c|c|c|}
\hline \multirow[t]{2}{*}{ Subject No } & \multicolumn{3}{|c|}{ Before immunisation } & \multicolumn{3}{|c|}{48 hours after immunisation and indomethacin capsules } & \multirow[t]{2}{*}{ Outcome } \\
\hline & $\begin{array}{l}\text { Baseline sGaw } \\
\left(s^{-1} \mathrm{kPa}^{-1}\right)\end{array}$ & $D_{20}(m g / m l)$ & $\begin{array}{l}\text { Slope } \\
\left(s^{-1} k \mathrm{~Pa}^{-1}\right)\end{array}$ & $\begin{array}{l}\text { Baseline sGaw } \\
\left(s^{-1} \mathrm{KPa}^{-1}\right)\end{array}$ & $D_{20}(m g / m l)$ & $\begin{array}{l}\text { Slope } \\
\left(s^{-1} k a^{-1}\right)\end{array}$ & \\
\hline $\begin{array}{l}a \\
b \\
c \\
d \\
e \\
f \\
g \\
h \\
i \\
j\end{array}$ & $\begin{array}{l}3.0 \\
3.5 \\
3.5 \\
3.0 \\
2.7 \\
2.9 \\
2.8 \\
2.7 \\
2.9 \\
3.7\end{array}$ & $\begin{array}{r}10 \cdot 7 \\
11.9 \\
8.6 \\
22.9 \\
7.2 \\
10 \cdot 8 \\
7.9 \\
10 \cdot 3 \\
2.5 \\
7.5\end{array}$ & $\begin{array}{l}-1.16 \\
-1.56 \\
-2.01 \\
-1.53 \\
-1.64 \\
-1.53 \\
-2.10 \\
-1.54 \\
-1.69 \\
-1.45\end{array}$ & $\begin{array}{l}3.2 \\
3.9 \\
3.4 \\
3.3 \\
3.0 \\
2.8 \\
2.7 \\
2.9 \\
3 \cdot 1 \\
4 \cdot 0\end{array}$ & $\begin{array}{r}4.7 \\
9.5 \\
7 \cdot 4 \\
20 \cdot 5 \\
9.5 \\
15.8 \\
1.8 \\
19.9 \\
5.9 \\
9.7\end{array}$ & $\begin{array}{l}-1 \cdot 37 \\
-2.05 \\
-2.83 \\
-2.28 \\
-2.06 \\
-2.74 \\
-1.03 \\
-2.38 \\
-3.07 \\
-2.76\end{array}$ & $\begin{array}{l}\mathbf{A} \\
\mathbf{C} / \mathbf{A} \\
\mathbf{C} / \mathbf{A} \\
\mathrm{C} \\
\mathbf{C} / \mathbf{A} \\
\mathrm{C} \\
\mathrm{C} / \mathbf{A} \\
\mathrm{C} \\
\mathbf{A} .\end{array}$ \\
\hline $\begin{array}{l}\text { Mean } \\
\text { SD } \\
\text { SEM }\end{array}$ & $\begin{array}{l}3 \cdot 1 \\
0 \cdot 36 \\
0 \cdot 12\end{array}$ & $\begin{array}{l}10 \cdot 1 \\
5 \cdot 25 \\
1 \cdot 66\end{array}$ & $\begin{array}{r}-1.62 \\
0.27 \\
0.09\end{array}$ & $\begin{array}{l}3 \cdot 2 \\
0 \cdot 44 \\
0 \cdot 14\end{array}$ & $\begin{array}{c}10 \cdot 5 \\
6 \cdot 32 \\
2 \cdot 00\end{array}$ & $\begin{array}{r}-2.26 \\
0.66 \\
0.21\end{array}$ & \\
\hline
\end{tabular}

C-coryzal symptoms; A-greater than four-fold rise in haemagglutination-inhibition antibody.

fall in baseline sGaw to a mean of $3.5 \mathrm{~s}^{-1} \mathrm{kPa}^{-1}$. There was a significant increase in sensitivity at this time with a fall in $\log D_{20}(p<0.002)$; the mean value of $D_{20}$ fell from 20.9 to $7.8 \mathrm{mg} / \mathrm{ml}$. There was, however, a concurrent decrease in reactivity $(\mathrm{p}<$ $0.002)$, the mean value of the slope then being $-1.30 \mathrm{~s}^{-1} \mathrm{kPa}^{-1}$.

Forty-eight hours after immunisation the group receiving indomethacin treatment showed a small but significant increase in baseline sGaw to $3.2 \mathrm{~s}^{-1}$ $\mathrm{kPa}^{-1}(\mathrm{p}<0.05)$. There was no significant change in $\log D_{20}$ but a significant increase in reactivity was found $(p<0.02)$, the mean value of the slope being $-2 \cdot 26 \mathrm{~s}^{-1} \mathrm{kPa}^{-1}$.

Forty-eight hours after immunisation there was no longer a significant difference in baseline sGaw values between the two treatment groups or in val- ues of $\log D_{20}$ (although the mean was now lower in the placebo treatment group). There was, however, a highly significant difference in reactivity, which was now greater in the indomethacin-treated group $(p<0.005)$. The change in sensitivity was significantly greater after immunisation plus placebo than after immunisation plus indomethacin $(\mathrm{p}<$ 0.02 for the absolute change in $D_{20}$ and $p<0.005$ for the change in $\log D_{20}$ ).

Linear regression analysis showed a significant positive correlation between control values of baseline sGaw and slope $(r=0.58, p<0.01)$, but there was no significant correlation between values of baseline sGaw and $D_{20}(r=0.05)$ or between control values of $D_{20}$ and slope $(r=0 \cdot 26)$.

There was no significant correlation between $\Delta \mathrm{sGaw}$ and $\Delta \mathrm{D}_{20}$ in either treatment group $(\mathrm{r}=0.39$ 
for placebo and 0.06 for indomethacin). Similarly, there was no significant correlation between $\Delta \mathrm{sGaw}$ and $\Delta$ slope $(r=0.40$ for placebo and 0.48 for indomethacin).

Five subjects from each group complained of coryzal symptoms (malaise, sore throat, hoarseness, or nasal congestion). Six subjects in the indomethacin-treatment group and five in the placebo group showed a greater than four-fold rise in HI antibody titre. Some subjects developed both. Only three subjects developed neither symptoms nor antibody rise-one treated with indomethacin and two with placebo. Both of these two, however, still showed a considerable increase in sensitivity to histamine.

\section{Discussion}

Influenza immunisation with live attenuated virus via the nasal route caused a significant increase in sensitivity to histamine in a group of otherwise healthy volunteers. This increase in sensitivity was prevented by treatment with indomethacin.

There was a higher mean baseline sGaw value in the subjects subsequently treated with placebo than in those treated with indomethacin and this was associated with a greater initial reactivity. This confirms the positive correlation between baseline sGaw and slope previously noted. ${ }^{12}$ After immunisation alone there was, paradoxically, a decrease in reactivity whereas after immunisation plus indomethacin there was in contrast a small but statistically significant increase in reactivity. These changes cannot be explained solely in terms of fluctuations in baseline sGaw, but possibly reflect modifications to the proposed prostaglandinmediated mechanisms within the airways which are thought to limit reactivity. ${ }^{13}$

In the present study there was little overlap between development of a rise in titre of antibody to influenza virus and coryzal symptoms, although 17 out of 20 subjects developed one or both. It is difficult to know which of these changes was more likely to be important in the present study. Further, two subjects in the placebo group who developed neither change showed considerable responsiveness after immunisation. In the study by Little $e t a^{7}$ a quarter of the hyperresponsive subjects failed to show an antibody rise during clinical influenza. Similarly, in the study by Laitinen $e$ al $^{10}$ only a half of the nasally immunised subjects developed a rise in antibody titre. Other authors have shown a poor correlation between a rise in viral antibody titre and coryzal symptoms. ${ }^{14}$

Influenza virus has been described as causing acute diffuse inflammation of larynx, trachea, and bronchi, worse distally, with mucosal injection and oedema. There may also be focal disturbance and desquamation of ciliated epithelium, leaving a thin covering of basal cells on a thickened and hyalinised basement membrane. ${ }^{11} 15$ One hypothesis to account for the hyperresponsiveness in these circumstances is that this pathological damage would expose and so "sensitise" irritant receptors in the airways, leading to enhancement of vagally mediated reflex bronchoconstriction. ${ }^{4}{ }^{16}$ Others have suggested that nerve endings situated in the oropharynx may be particularly affected. ${ }^{8}$ The detailed pathological changes after influenza immunisation with live attenuated virus have not been documented but are presumably qualitatively similar to but less intense than the changes induced by the wild virus. Thus similar mechanisms of heightened vagal reflex activity could also be concerned in the pathogenesis of hyperresponsiveness after immunisation. Allergic reactions to antigen in the vaccine do not seem to play a part. ${ }^{9}$

Others have suggested that the influenza virus may decrease responses to $\beta$-adrenergic and other bronchodilator agonist stimulation in the airways, leading to exaggeration of bronchoconstrictor responses. ${ }^{17}$ Evidence for this theory has come indirectly from studies on the release mechanism of lysosomal enzymes from polymorphonuclear neutrophils incubated in vitro. Normally this release is inhibited by $\beta$-adrenergic, histamine- $2\left(\mathrm{H}_{2}\right)$, and $\mathrm{PGE}_{2}$ receptor stimulation via adenyl cyclase activation and cyclic AMP generation. Incubation of live influenza $A$ and $B$ virus vaccine with granulocytes decreases all these inhibitory influences. ${ }^{18} 19$ Neutrophils from patients with asthma show an impairment of $\beta$-adrenergic and $\mathrm{H}_{2}$-induced inhibition of enzyme release, although the response to PGE is normal. ${ }^{20}$ During a respiratory tract infection precipitating bronchospasm in asthmatic patients the $\beta$-adrenergic response is further impaired. ${ }^{17} \mathrm{~A}$ similar effect during viral infections may also occur in normal people. ${ }^{14}$

Another hypothesis, based on the results of the current experiments, is that prostaglandins generated as a part of the inflammatory response to viral infection in the airways mediate the increase in sensitivity to histamine. The change could well be at the level of the airways smooth muscle itself. A change in vagal reflex activity cannot be excluded, however, and prostaglandins could be responsible for "sensitisation" of airways irritant receptors. ${ }^{16}$

I am indebted to Professor CW Potter, department of virology, Sheffield University, for measuring the antiviral antibody titres and for his advice on the study. 


\section{References}

${ }^{1}$ Lambert HP, Stern H. Infective factors in exacerbations of bronchitis and asthma. Br Med J 1972;iii:323-7.

${ }^{2}$ Minor TE, Dick EC, Baker JW, Ouellette JJ, Cohen M, Reed CE. Rhinovirus and influenza type A infections as precipitants of asthma. Am Rev Respir Dis 1976; 113:149-53.

${ }^{3}$ Parker CD, Bilbo RE, Reed CE. Methacholine aerosol as a test for bronchial asthma. Arch Intern Med 1965;115:452-8.

${ }^{4}$ Empey DW, Laitinen LA, Jacobs L, Gold WM, Nadel JA. Mechanisms of bronchial hyper-reactivity in normal subjects after upper respiratory tract infection. Am Rev Respir Dis 1976;113:131-9.

${ }^{5}$ Hall WJ, Douglas RG, Hyde RW, Roth FK, Cross AS, Speers DM. Pulmonary mechanics after uncomplicated influenza A infection. Am Rev Respir Dis 1976;113:141-7.

${ }^{6}$ Little JW, Hall WJ, Douglas RG, Hyde RW, Speers DM. Amantadine effect on peripheral airways abnormalities in influenza. Ann Intern Med 1976;85:177-82.

${ }^{7}$ Little JW, Hall WJ, Douglas RG, Mudholkar GS, Speers DA, Patel K. Airway hyper-reactivity and peripheral airway dysfunction in influenza A infection. $A m R e v$ Respir Dis 1978;118:295-303.

${ }^{8}$ Aquilina AT, Hall WJ, Douglas RG, Utell MJ. Airway reactivity in subjects with viral upper respiratory tract infections: the effect of exercise and cold air. Am Rev Respir Dis 1980;122:3-10.

9 Ouellette JJ, Reed CE. Increased response of asthmatic subjects to methacholine after influenza vaccine. $J$ Allergy Clin Immunol 1965;36:558-63.

${ }^{10}$ Laitinen LA, Elkin RB, Empey DW, Jacobs L, Mills J, Gold WM, Nadel JA. Changes in bronchial reactivity after administration of live attenuated influenza virus. Am Rev Respir Dis 1976;113:194.
${ }^{11}$ Walsh JJ, Dietlein LF, Low FN, Bunch GE, Mogabgab WJ. Tracheobronchial response in human influenza. Arch Intern Med 1961;108:376-88.

12 Walters EH, Davies BH, Smith AP. Measurement of bronchial reactivity: a question of interpretation. Thorax 1981;36:960.

${ }^{13}$ Grodzinska L, Panczenko B, Gryglewski RJ. Generation of prostaglandin E-like material by the guinea-pig trachea contracted by histamine. J Pharm Pharmacol 1975;27:88-91.

${ }^{14}$ Bush RF, Busse W, Flaherty D, Warshauer D, Dick EC, Reed CE. Effects of experimental rhinovirus 16 infection on airways and leukocyte function in normal subjects. J Allergy Clin Immunol 1978;61:80-7.

${ }^{15}$ Hers JFP, Mulder J. Broad aspects of the pathology and pathogenesis of human influenza. Am Rev Respir Dis 1961;83:84-9.

${ }^{16}$ Nadel JA. Mechanisms of airways hyperirritability: role of epithelial damage. In: Sadoul P, Milic-Emili J, Simonsson BG, Clark TJH, eds. Small airways in health and disease. Amsterdam: Excerpta Medica, 1979:68-73.

${ }^{17}$ Busse WW. Decreased granulocyte response to isoproterenol in asthma during upper respiratory infections. Am Rev Respir Dis 1977;115:783-91.

${ }^{18}$ Busse WW, Cooper W, Warshauer DM, Dick EC, Wallow IHL, Albrecht R. Impairment of isoproterenol, $\mathrm{H}_{2}$ histamine, and prostaglandin $\mathrm{E}_{1}$ response of human granulocytes after incubation in vitro with live influenza vaccines. Am Rev Respir Dis 1979; 119:561-9.

${ }^{19}$ Busse WW, Reed CE. In vitro studies on the mechanism of respiratory virus-induced asthma. Chest 1979;75: 234S.

${ }^{20}$ Busse W, Cooper W, Rowe C. Cortisol protection of the granulocyte response to isoproterenol during in vitro influenza viral vaccine incubation. J Allergy Clin Immunol 1976;63:147-8. 